\title{
SISTEM PAKAR BERBASIS ANDROID UNTUK MENDETEKSI JENIS PERILAKU
} ADHD PADA ANAK

\author{
Muhammad Alkaff ${ }^{1}$, Husnul Khatimi ${ }^{2}$, Yuslena Sari ${ }^{3}$, Puja Darmawan ${ }^{4}$, Rakhmadhany Primananda ${ }^{5}$ \\ Program Studi Teknologi Informasi, Fakultas Teknik, Universitas Lambung Mangkurat ${ }^{1,2,3,4}$ \\ Program Studi Teknik Komputer, Fakultas Ilmu Komputer, Universitas Brawijaya ${ }^{5}$ \\ ${ }^{1}$ m.alkaff@ulm.ac.id, ${ }^{2}$ hkhatimi@ulm.ac.id, ${ }^{3}$ yuzlena@ulm.ac.id, ${ }^{4}$ pujadarmawan7@ gmail.com, \\ ${ }^{5}$ rakhmadhany@ub.ac.id
}

(Naskah masuk: 19 November 2018, diterima untuk diterbitkan: 18 Desember 2018)

\begin{abstract}
Abstrak
ADHD (Attention Deficit Hyperactivity Disorder) adalah gangguan perkembangan otak pada anak yang mengakibatkan meningkatnya aktifitas motorik sehingga menyebabkan penderitanya menjadi hiperaktif, impulsif dan inatentif. Kondisi ini sering memperlihatkan tingkah laku yang tidak wajar seperti selalu bergerak tanpa tujuan, selalu gelisah, atau tidak bisa duduk dengan tenang. Gangguan ADHD terbagi menjadi tiga jenis yaitu Hiperaktif, Inatentif dan Impulsif. Salah satu cara untuk mendiagnosa jenis ADHD yang diderita oleh anak adalah dengan konseling. Tujuan dari penelitian ini adalah membangun sebuah sistem pakar yang dapat membantu memberikan kesimpulan tentang jenis penyakit ADHD yang diderita oleh anak serta tingkat keyakinan diagnosisnya. Penelitian ini menggunakan metode Dempster-Shafer untuk melakukan perhitungan terhadap nilai keyakinan suatu diagnosa. Hal ini dilakukan dengan cara membandingkan setiap nilai keyakinan dari 2 gejala awal yang terjadi pada anak untuk selanjutnya dibandingkan lagi dengan nilai keyakinan dari gejala-gejala lainnya. Sehingga mengerucut pada suatu gejala yang mengacu kepada suatu jenis dari ADHD disertai dengan nilai keyakinannya seperti layaknya diagnosa seorang pakar psikologi anak. Dalam penelitian ini dibangun sistem pakar berbasis Android dengan basis pengetahuan dari 3 orang pakar untuk memudahkan orang tua anak dalam mendiagnosa gejala-gelaja yang mungkin diderita oleh anaknya. Hasil pengujian sistem terhadap pakar dengan persentase rata-rata sebesar $90 \%$ dari 3 orang pakar, menunjukan bahwa sistem pakar yang telah dibuat mampu mendiagnosa jenis perilaku ADHD yang diderita oleh anak-anak disertai dengan nilai tingkat keyakinan diagnosisnya.
\end{abstract}

Kata kunci: sistem pakar, ADHD, dempster-shafer, Android

\section{ANDROID BASED EXPERT SISTEM TO DETECT TYPES OF ADHD BEHAVIOR ON CHILDREN}

\begin{abstract}
ADHD (Attention Deficit Hyperactivity Disorder) is a brain development disorder in children resulting in increased motor activity causing the sufferer to become hyperactive, impulsive and inattentive. This condition often shows unnatural behavior like always moving aimlessly, always restless, or unable to sit quietly. ADHD disorders divided into three types, namely Hyperactive, Inattentive and Impulsif. One way to diagnose the type of ADHD suffered by children is by counseling. The purpose of this study is to build an expert sistem that can help provide conclusions about the kind of ADHD that the children had and the diagnosis level of confidence. This research uses Dempster-Shafer method to perform the calculation of confidence value of diagnosis. This is done by comparing each of the confidence values of the two early symptoms that occur in the child to furthermore compare with the belief value of the other symptoms. Therefore, conical to a symptom that refers to a type of ADHD accompanied by the value of the diagnosis beliefs, just like the diagnosis of a child psychologist. In this study, an Android-based expert system with a knowledge base from three experts is built to facilitate the child's parents in diagnosing symptoms that may be suffered by his son. The experimental test of the system with the mean percentage of $90 \%$ from 3 experts, indicates that the expert system that has been made can diagnose the type of ADHD behavior suffered by the children accompanied by the value of the diagnosis confidence level.
\end{abstract}

Keywords: expert system, ADHD, dempster-shafer, Android

\section{PENDAHULUAN}

Attention Deficit Hyperactivity Disorder (ADHD) sering dianggap sebagai cacat kehidupan yang mengganggu aktifitas sosial penderitanya. Berdasarkan data hasil Survei Sosial Ekonomi Nasional (SUSENAS) tahun 2016 dari Badan Pusat 
Statistik (BPS) menunjukkan bahwa, dari 4,6 juta anak yang tidak sekolah, satu juta di antaranya adalah anak-anak berkebutuhan khusus (Badan Pusat Statistik, 2016). Akan tetapi, belum ada data pasti tentang data penderita ADHD di Indonesia dikarenakan peningkatan jumlah kasusnya sangat bervariasi (Cortese, dkk, 2007).

ADHD adalah suatu gangguan yang mempengaruhi perkembangan dalam peningkatan aktivitas motorik anak-anak sehingga berdampak pada aktivitas anak-anak yang tidak lazim dan cenderung berlebihan (Adiputra, dkk, 2015). ADHD ditandai dengan ketidakmampuan anak untuk memusatkan dan mempertahankan perhatian, mengontrol tingkat aktivitas, dan tindakan impulsif terhadap sesuatu (Rappley, 2005). Pada umumnya, anak yang menderita ADHD akan mulai bermasalah apabila sudah mulai masuk playgroup atau sekolah. Anak yang menderita ADHD akan mengalami kesulitan dalam memusatkan perhatian sehingga tidak dapat menyelesaikan tugas-tugas yang diberikan kepadanya secara baik (Ridwan, 2013).

ADHD dapat diklasifikasikan menjadi 3 jenis yaitu Hiperaktif, Inatentif, dan Impulsif. Anak dengan jenis kelainan hiperaktif cenderung memiliki aktifitas yang sulit dikontrol, selalu aktif bergerak seakan tidak merasakan lelah dan tidak bisa diam. Gejala yang biasa terlihat adalah selalu gelisah saat bermain, susah untuk diam, selalu aktif bergerak seperti berlari atau memanjat pada sesuatu dan tidak bias duduk dengan tenang.

Anak yang menderita gangguan inatentif cenderung lebih kesulitan untuk memperhatikan sesuatu, gejala yang sering terlihat adalah penderita akan kesulitan untuk memusatkan perhatian, terlihat acuh dan tidak mendengarkan ketika orang lain berbicara, mudah beralih perhatian, sering melakukan kesalahan dikarenakan ceroboh, sulit diatur dan mengerjakan tugas yang diterima, tidak bisa menyimpan barang yang diberikan kepadanya dan memiliki kecenderungan mengigau saat tidur. Impulsif merupakan gangguan yang aktifitasnya sering dilakukan dengan ceroboh. Gejala yang biasanya terlihat adalah sangat sulit untuk menunggu giliran, menjawab pertanyaan tanpa dasar dan memaksa menjawab walaupun belum diberi kesempatan sering menginterupsi orang lain dan bertindak impulse tanpa memikirkan konsekuensinya seperti berlari ditengah acara formal, mengejar sesuatu yang berbahaya.

Permalahan yang dihadapi orang tua dari anak yang menderita $\mathrm{ADHD}$ adalah ketidaktahuan mereka bahwa anak mereka mengidap kelainan ADHD. Hal ini mungkin sulit dilihat oleh orang tua yang awam akan maksud dari tingkah laku anaknya, sehingga kelainan ini akan dapat diketahui setelah orang tua berkonsultasi dengan ahlinya.

Dengan semakin berkembangnya ilmu pengetahuan serta teknologi. Pengetahuan para ahli atau pakar dapat diimplementsikan ke dalam suatu sistem yang disebut sebagai sistem pakar. Dengan menerapkan sistem pakar, perangkat lunak pada komputer akan mampu memodelkan kemampuan dalam menyelesaikan masalah seperti layaknya seorang pakar. Sistem pakar adalah sistem yang terintegrasi dengan perangkat komputer yang di dalamnya terdapat pengetahuan, fakta, dan teknik penalaran dalam memecahkan masalah yang biasanya hanya dapat dipecahkan oleh seorang pakar dalam bidang tersebut. Sistem pakar memberikan nilai tambah pada teknologi untuk membantu dalam menangani era informasi yang semakin canggih (Kusrini, 2006).

Penelitian menggunakan sistem pakar untuk mendiagnosa jenis gangguan ADHD pada anak telah dilakukan, beberapa diantaranya oleh Evi Destiani Hulaifah dalam penelitainnya yang berjudul Sistem Pakar Untuk Menentukan Tipe Gangguan ADHD Pada Anak Dengan Metode Naïve Bayes (Hulaifah, dkk, 2015). Kemudian oleh Donny Priyo Joyo dengan judul Sistem Pakar Untuk Mendiagnosis Gangguan Perilaku Dan Sifat Pada Anak menggunakan Metode Fuzzy Expert Sistem (Joyo, 2013). Hasil uji coba data, kedua peneltian diatas memberikan akurasi sebesar $90 \%$. Penelitian lainnnya juga dilakukan oleh Siti Rahmadini dengan menggunakan metode yang berbeda yaitu Dempster-Shafer dalam penelitiannya dengan judul Sistem Pakar Diagnosa Penyimpangan Tumbuh Kembang Anak Menggunakan Metode Dempster-Shafer . Pada uji validasi, akurasi yang dihasilkan sedikit lebih besar dari 2 penelitian yang disebutkan di atas yaitu 92\% (Rahmadini, 2016).

Mengacu pada beberapa penelitan yang sudah disebutkan di atas, dan melihat tingkat akurasi yang dihasilkan dari masing-masing metode maka dalam penelitian ini menggunakan metode DempsterShafer. Penggunaan metode Dempster-Shafer dianggap lebih cocok dikarenakan prinsip dasar dari metode ini yang menggabungkan bukti-bukti independen yang dilakukan pakar kepada non pakar (Shafer, 1992). Hal tersebut sesuai dengan salah satu pendekatan yang paling sering digunakan dalam diagnosis dalam dunia kedokteran yaitu anamnesis.

Salah satu kelemahan dari sistem pakar adalah sifat dasarnya yang subjektif tergantung dari pakar yang diacu sebagai sumber pengetahuan di sistem tersebut. Oleh karena itu, dalam penelitian ini, digunakan 3 orang pakar dari latar belakang yang berbeda sebagai sumber pengetahuan. Hal ini untuk meminimalisir tingkat subjektifitas dari masingmasing pakar. Kemudian data yang didapat dari 3 orang pakar akan diproses menggunakan metode Dempster-Shafer. Kemudian sistem pakar dibangun menggunakan platform mobile berbasis Android.

Platform mobile dipilih untuk memudahkan para orang tua untuk melakukan diagnosa awal tentang kecenderungan anaknya menderita ADHD. Hal ini diperkuat dengan penetrasi smartphone yang begitu masif. Berdasarkan survey yang dilakukan oleh Asosiasi Penyelenggara Jasa Internet Indonesia 
(APJII) presentasi kepemilikan smartphone mencapai $50.08 \%$ dari total populasi penduduk Indonesia (APJII, 2017). Sementara menurut data survey Statista, dari seluruh pengguna smartphone di Indonesia, $88.37 \%$ menggunakan smartphone dengan sistem operasi Android (Statista, 2018).

\section{METODE PENELITIAN}

Data yang digunakan dalam penelitian ini merupakan data primer yang didapat langsung dari 3 orang pakar di wilayah Banjarmasin. Dua orang pakar merupakan terapis ADHD dan juga pendidik di Pusat Layanan Autis Banjarmasin (PLA) dan satu orang pakar lainnya merupakan dosen di Fakultas Kedokteran Program Studi Psikologi Universitas Lambung Mangkurat Banjarbaru.

Data yang dikumpulkan berupa gejala-gejala yang mendukung 3 jenis gangguan ADHD (Hiperaktif, Inatentif dan Impulsif). Masing -masing gejala memiliki nilai belief atau nilai tingkat keyakinan yang berbeda kemudian data tersebut akan diproses menggunakan perhitungan metode Dempster Shafer. Total gejala yang sudah diverifikasi oleh pakar sebanyak 34 gejala serta nilai belief dari masing-masing gejala. Tabel basis pengetahuan gejala dapat dilihat pada Tabel 1 .

Tabel 1. Basis Pengetahuan Gejala ADHD

\begin{tabular}{|c|c|}
\hline Kode & Nama Gejala \\
\hline G1 & Susah untuk bersikap disiplin \\
\hline G2 & Sangat sensitive bila mendapat kritik/teguran \\
\hline G3 & Tidak banyak memiliki teman \\
\hline G4 & $\begin{array}{l}\text { Cenderung tidak menyukai kegiatan yg memerlukan } \\
\text { usaha berkesinambungan, contoh duduk diam. }\end{array}$ \\
\hline G5 & Merasa cemas dengan suatu lingkungan yang baru \\
\hline G6 & Sering melamun \\
\hline G7 & $\begin{array}{l}\text { Tidak memiliki rasa percaya diri yang tinggi dan } \\
\text { selalu merasa rendah diri }\end{array}$ \\
\hline G8 & Sering merasa khawatir dan takut \\
\hline G9 & $\begin{array}{l}\text { Menjawab suatu pertanyaan tanpa berpikir } \\
\text { sedangkan pertanyaan tersebut belum selesai }\end{array}$ \\
\hline G10 & $\begin{array}{l}\text { Apabila sedang bermain, lebih sering mondar mandir } \\
\text { dan susah untuk bermain dengan tenang }\end{array}$ \\
\hline G11 & Bicara sesuatu yang tidak perlu dan berlebihan \\
\hline G12 & Sering menghentak-hentakan kaki ketika duduk diam \\
\hline G13 & Sering iseng/jahil dengan anak lainnya \\
\hline G14 & Tidak suka menunggu giliran \\
\hline G15 & Sering merebut mainan teman dengan paksa \\
\hline G16 & Reaktif terhadap sesuatu yang dilakukan terhadapnya \\
\hline G17 & $\begin{array}{l}\text { Sering mengulang-ulang sesuatu yang diucapkan } \\
\text { orang lain }\end{array}$ \\
\hline G18 & Sering bertindak kasar dengan teman sebaya \\
\hline G19 & Memiliki sikap menantang dan membangkang \\
\hline G20 & $\begin{array}{l}\text { Sulit untuk menaati aturan dan cenderung melanggar } \\
\text { aturan tersebut. }\end{array}$ \\
\hline G21 & $\begin{array}{l}\text { Selalu bermasalah dengan orang-orang yang } \\
\text { memiliki otoritas }\end{array}$ \\
\hline G22 & $\begin{array}{l}\text { Sering merasa terganggu dan marah dengan orang } \\
\text { lain }\end{array}$ \\
\hline G23 & Terlihat sangat pemalu dan minder \\
\hline G24 & Mudah lupa, contoh mainan sering tertinggal \\
\hline G25 & $\begin{array}{l}\text { Perhatiannya mudah diganggu (terutama terhadap } \\
\text { suara) }\end{array}$ \\
\hline G26 & Cenderung tidak mendengarkan ketika orang bicara \\
\hline G27 & Kesulitan dalam mengatur tugas/kegiatan sehari hari \\
\hline G28 & $\begin{array}{l}\text { Sulit menuruti petunjuk atau arahan yang diberikan } \\
\text { guru atau orang tua }\end{array}$ \\
\hline G29 & $\begin{array}{l}\text { Tidak mau menerima tugas yang diberikan guru atau } \\
\text { orang tua }\end{array}$ \\
\hline
\end{tabular}

\begin{tabular}{cl}
\hline Kode & \multicolumn{1}{c}{ Nama Gejala } \\
\hline G30 & $\begin{array}{l}\text { Mudah melupakan kegiatan yang sudah } \\
\text { dikerjakannya }\end{array}$ \\
\hline G31 & Selalu aktif bergerak, contoh berlari dan memanjat \\
\hline G32 & Sering menggeliat \\
\hline G33 & Sering membuat suasana menjadi tidak tenang \\
\hline G34 & $\begin{array}{l}\text { Selalu merasa penasaran dengan benda yang } \\
\text { dilihatnya sehingga membuatnya menyentuh benda } \\
\text { tersebut }\end{array}$ \\
\hline Alur proses dari sistem pada penelitian ini dapat
\end{tabular}
digambarkan dengan sederhana melalui diagram alir seperti dapat dilihat pada Gambar 1.

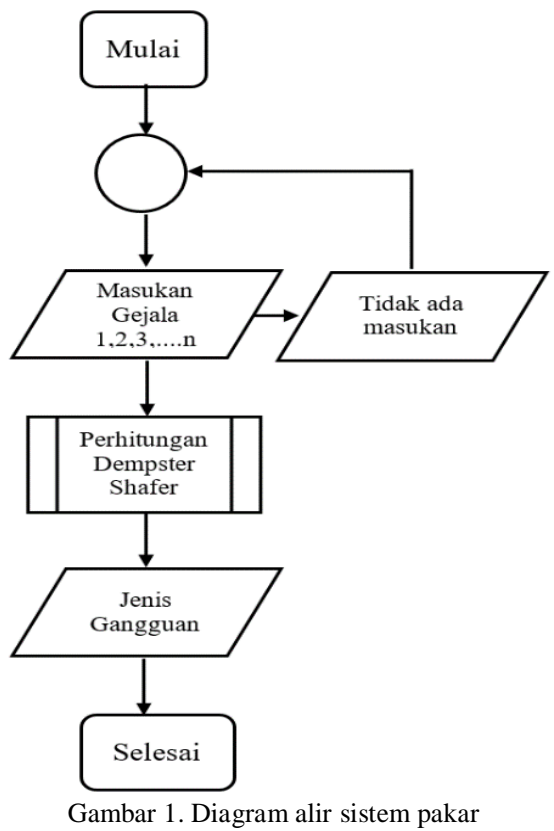

\section{HASIL DAN PEMBAHASAN}

Dari pengujian data sebanyak 10 kasus ADHD akan diverifikasi oleh pakar dengan cara pakar akan melakukan diagnosa terhadap 10 kasus yang telah diproses dengan sistem kemudian membandingkan hasil dari diagnosa pakar dengan hasil akhir dari proses yang dikeluarkan sistem dengan pengetahuan yang bersumber dari pakar terkait penelitian diatas untuk mendapatkan keakuratan hasil dari system pakar yang telah dibuat untuk seterusnya digunakan oleh user seperti dapat dilihat pada Tabel 1, Tabel 2, dan Tabel 3.

\begin{tabular}{cccc}
\multicolumn{4}{c}{ Tabel 2. Perbandingan Hasil Dengan Pakar 1 } \\
\hline Pengujian & $\begin{array}{c}\text { Hasil } \\
\text { Diagnosa } \\
\text { Pakar }\end{array}$ & $\begin{array}{c}\text { Hasil } \\
\text { Diagnosa } \\
\text { Sistem }\end{array}$ & Kesimpulan \\
\hline 1 & In, Hip, Im & $\begin{array}{c}\text { In, Hip, Im } \\
46,56 \%\end{array}$ & Sesuai \\
\hline 2 & Impulsif & $\begin{array}{c}\text { Impulsif } \\
94,34 \%\end{array}$ & Sesuai \\
\hline 3 & Inatentif & $\begin{array}{c}\text { Inatentif } \\
87,74 \%\end{array}$ & Sesuai \\
\hline 4 & Hiperaktif & $\begin{array}{c}\text { Hiperaktif } \\
98,16 \%\end{array}$ & Sesuai \\
\hline 5 & Impulsif & $\begin{array}{c}\text { Impulsif } \\
99,29 \%\end{array}$ & Sesuai \\
\hline 7 & Inatentif & $\begin{array}{c}\text { Inatentif } \\
99,58 \%\end{array}$ & Sesuai \\
\hline
\end{tabular}




\begin{tabular}{|c|c|c|c|}
\hline Pengujian & $\begin{array}{c}\text { Hasil } \\
\text { Diagnosa } \\
\text { Pakar }\end{array}$ & $\begin{array}{c}\text { Hasil } \\
\text { Diagnosa } \\
\text { Sistem }\end{array}$ & Kesimpulan \\
\hline 8 & Hiperaktif & $\begin{array}{c}\text { Hiperaktif } \\
91,20 \%\end{array}$ & Sesuai \\
\hline 9 & Intatentif & $\begin{array}{c}\text { Intatentif } \\
67,46 \%\end{array}$ & Sesuai \\
\hline 10 & Impulsif & $\begin{array}{l}\text { Impulsif } \\
49,60 \%\end{array}$ & Sesuai \\
\hline \multicolumn{2}{|c|}{ Total } & \multicolumn{2}{|c|}{$100 \%$} \\
\hline \multicolumn{4}{|c|}{ Tabel 3. Perbandingan Hasil Dengan Pakar 2} \\
\hline Pengujian & $\begin{array}{c}\text { Hasil } \\
\text { Diagnosa } \\
\text { Pakar }\end{array}$ & $\begin{array}{c}\text { Hasil } \\
\text { Diagnosa } \\
\text { Sistem }\end{array}$ & Kesimpulan \\
\hline 1 & In, Hip, Im & $\begin{array}{c}\text { In, Hip, Im } \\
46,56 \%\end{array}$ & Sesuai \\
\hline 2 & Impulsif & $\begin{array}{l}\text { Impulsif } \\
94,34 \%\end{array}$ & Sesuai \\
\hline 3 & Inatentif & $\begin{array}{c}\text { Inatentif } \\
87,74 \%\end{array}$ & Sesuai \\
\hline 4 & Hiperaktif & $\begin{array}{c}\text { Hiperaktif } \\
98,16 \%\end{array}$ & Sesuai \\
\hline 5 & Impulsif & $\begin{array}{l}\text { Impulsif } \\
99,29 \%\end{array}$ & Sesuai \\
\hline 6 & Inatentif & $\begin{array}{l}\text { Inatentif } \\
99,58 \%\end{array}$ & Sesuai \\
\hline 7 & $\begin{array}{l}\text { Hiperaktif, } \\
\text { Inatentif }\end{array}$ & $\begin{array}{c}\text { Hiperaktif } \\
74,59 \%\end{array}$ & $\begin{array}{c}\text { Tidak } \\
\text { Sesuai } \\
\end{array}$ \\
\hline 8 & Hiperaktif & $\begin{array}{c}\text { Hiperaktif } \\
91,20 \%\end{array}$ & Sesuai \\
\hline 9 & Intatentif & $\begin{array}{c}\text { Intatentif } \\
67,46 \%\end{array}$ & Sesuai \\
\hline 10 & Impulsif & $\begin{array}{c}\text { Impulsif } \\
49,60 \%\end{array}$ & Sesuai \\
\hline \multicolumn{2}{|c|}{ Total } & \multicolumn{2}{|c|}{$90 \%$} \\
\hline
\end{tabular}

Setelah melewati tahap pengujian, tahapan selanjutnya adalah memindahkan basis pengetahuan ke dalam aplikasi mobile berbasis Android, sehingga sistem pakar dapat melakukan diagnosa terhadap gejala-gejala yang dipilih oleh orang tua anak. Berikut merupakan proses alur sistem yang dimulai dari memasukan gejala hingga memberikan kesimpulan berupa jenis gangguan ADHD yang diderita. Tampilan halaman basis pengetahuan gejala pada sistem dapat dilihat pada Gambar 2.

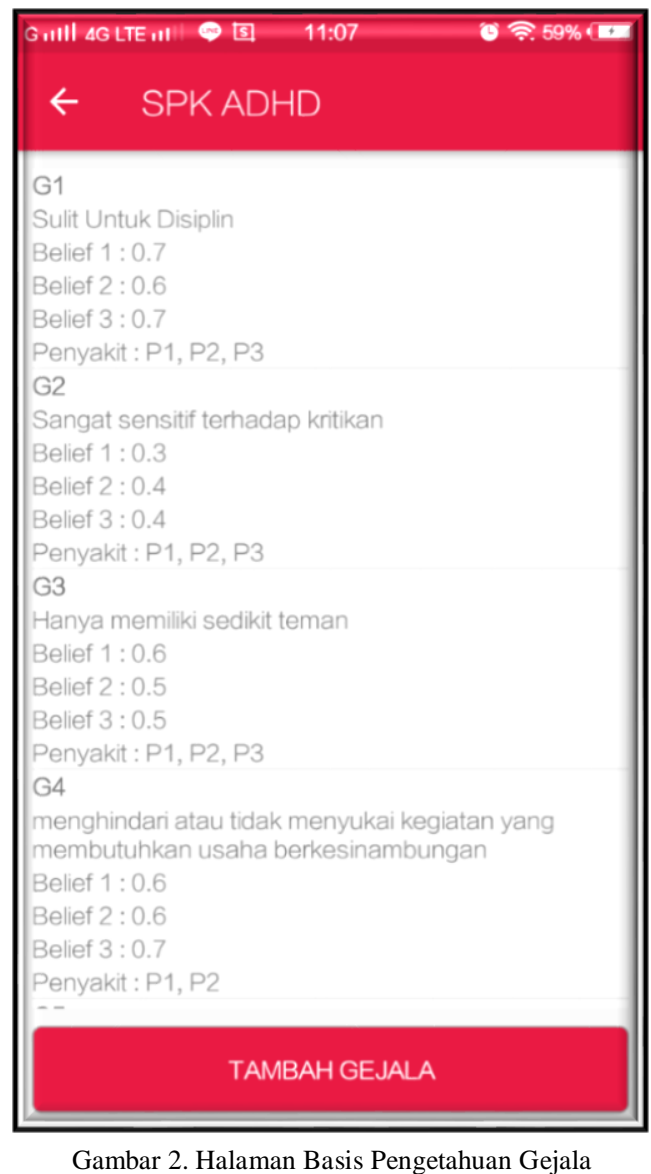

Selanjutnya pada halaman diagnosa, user diharuskan menjawab pertanyaan berupa gejalagejala yang berkaitan dengan jenis gangguan ADHD. Setelah semua pertanyaan diselesaikan, sistem akan mulai menghitung dan memberikan kesimpulan diagnose berupa jenis gangguan ADHD yang diderita. Halaman diagnosa gejala dapat dilihat pada Gambar 3.

Setelah user menjawab semua pertanyaan pada halaman diagnosa. Sistem kemudian akan menampilkan hasil diagnose berdasarkan gejala terpilih pada halaman hasil diagnosa. Pada halaman hasil diagnosa tipe ADHD akan ditampilkan berdasarkan gejala yang telah dipilih user beserta tingkat keyakinan dari diagnosa tersebut. Halaman hasil diagnosa dapat dilihat pada Gambar 4. 


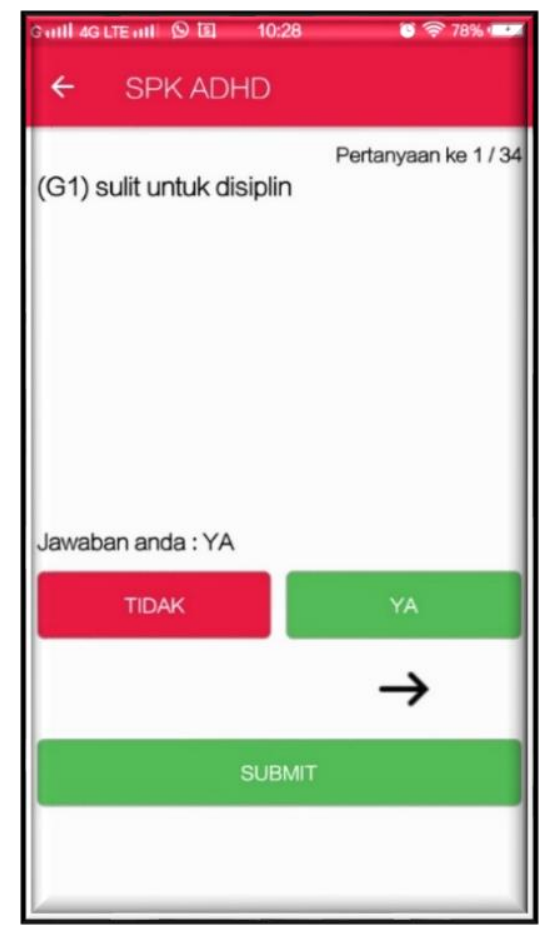

Gambar 3. Halaman Diagnosa

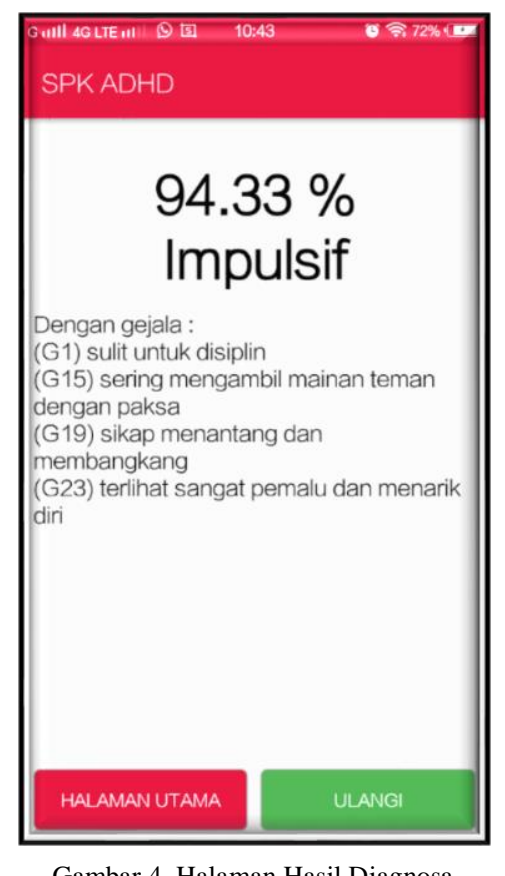

\section{KESIMPULAN}

Penelitian ini bertujuan membangun suatu sistem pakar dengan platform mobile berbasis Android dengan basis pengetahuan dari 3 orang pakar. Dari pengujian yang dilakukan terharap 10 kasus ADHD, didapatkan bahwa sistem dapat menghasilkan diagnosa sesuai dengan pakar pertama untuk semua kasus yang diujikan. Pakar kedua menghasilkan diagnosa sesuai untuk 9 dari 10 kasus yang diujikan. Pakar ketiga menghasilkan diagnosa sesuai untuk 8 dari 10 kasus yang diujikan. Sehingga apabila digabungkan rata-rata kesesuaian diagnosa dari sistem mencapai $90 \%$.

Diharapkan dengan adanya sistem ini, dapat memudahkan bagi para orang tua untuk melakukan diagnosa awal pada anak yang ditengarai menderita ADHD tanpa harus menemui langsung pakar psikologi anak.

\section{DAFTAR PUSTAKA}

ADIPUTRA, I.M.S., SUTARGA, I.M. and PINATIH, G.N.I., 2015. Risk Factors of Attention Deficit Hyperactivity Disorder (ADHD) among Children in Denpasar. Public Health and Preventive Medicine Archive, 3(1)

APJII, 2017. Penetrasi \& Perilaku Pengguna Internet Indonesia 2017. Asosiasi Penyelenggara Jasa Internet Indonesia, pp.1-39.

Badan Pusat Statistik, 2016. Survei Sosial Ekonomi Nasional. Jakarta: BPS.

CORTESE, S., BERNADINA, B.D. and MOUREN, M.-C., 2007. Attention-deficit/hyperactivity disorder (ADHD) and binge eating. Nutrition reviews, 65(9), pp.404-411.

HULAIFAH, E.D., NASUTION, H. and ANRA, H.H., 2015. Sistem Pakar Untuk Menentukan Tipe Gangguan ADHD Pada Anak Dengan Metode Naive Bayes. JUSTIN (Jurnal Sistem dan Teknologi Informasi), 4(1), pp.51-54.

JOYO, D., 2013. Sistem Pakar untuk Mendiagnosis Gangguan Perilaku dan Sifat pada Anak Menggunakan Metode Fuzzy Expert System.

KUSRINI, S., 2006. Kom. Sistem Pakar, Teori dan Aplikasi. Penerbit Andi Yogyakarta.

RAHMADINI, S., 2016. Pemodelan Sistem Pakar Diagnosa Penyimpangan Tumbuh Kembang Anak Menggunakan Metode DempsterShafer. Doro Jurnal, 7(8).

RAPPLEY, M.D., 2005. Attention deficithyperactivity disorder. New England Journal of Medicine, 352(2), pp.165-173.

RIDWAN, 2013. Peran sekolah bagi anak adhd. AtTalim, 4.

SHAFER, G., 1992. Dempster-shafer theory. Encyclopedia of artificial intelligence, pp.330-331.

Statista, 2018. Mobile OS: market share in Indonesia 2012-2017| Statistic. [online] January 2018. Available at: <https://www.statista.com/statistics/262205 /market-share-held-by-mobile-operatingsystems-in-indonesia/> [Accessed 11 Feb. 2018]. 
Halaman ini sengaja dikosongkan 